\title{
Reflecting on the Cognitive-Social Debate in Second Language Acquisition
}

\author{
DIANE LARSEN-FREEMAN \\ English Language Institute \\ 500 E Washington \#1025 \\ University of Michigan \\ Ann Arbor, MI 48104 \\ Email: dianelf@umich.edu
}

\begin{abstract}
Firth and Wagner's (1997) call for a more socially and contextually situated view of second language acquisition (SLA) research has generated a great deal of discussion and debate, a summary of which is offered in this reflective commentary. Given the individualistic, cognitive origin of the SLA field, such controversy is entirely understandable. With different ontologies and epistemologies, the two views, individual/cognitive and social/contextual, have had little impact on each other. These days, a theoretical pluralism prevails. Eventually, their differences may, though it is not clear that they will, be settled empirically. Another possibility is for there to be a reframing of our understanding, and I offer chaos/complexity theory as one means for doing so. Indeed, the solution the SLA field has perennially adopted when there are conflicting views is to seek a larger frame, one that acknowledges the contributions of each perspective. More specifically, I expect that it will be the point where the two perspectives intersect that will prove to be the most productive for future understanding of SLA, and I believe that there is a new consensus around this point that is emerging.
\end{abstract}

I WAS IN ATTENDANCE AT THE 1996 INTERNational Association of Applied Linguistics (AILA) Congress in Jyväskylä, Finland, where Firth and Wagner gave the focal paper of the present issue, although I was participating in a concurrent session and did not hear them present their paper. Nevertheless, as I was leaving my session and making my way to another, the doors on the room where Firth and Wagner had just spoken flung open, and I was quickly enveloped in the exiting crowd. Their excitement was palpable. For many, that day in August must have seemed a watershed moment. The perceived dominance of a cognitive, mentalistic orientation to second language acquisition (SLA) had been challenged. Scholars who had previously felt excluded found a rallying point in the Firth and Wagner paper; those who believed that their positions had been ignored felt empowered in a way that they had not before.

The Modern Language Journal, 91, Focus Issue, (2007) 0026-7902/07/773-787 \$1.50/0

(C)2007 The Modern Language Journal
I have been asked to provide a reflective commentary on the debate in the Autumn 1997 and Spring 1998 issues of The Modern Language Journal $(M L J)$ that followed the publication of Firth and Wagner's 1996 AILA paper in the same journal. In order to situate the paper and the ensuing debate, I will first provide a brief genealogy of the field of SLA. Next, I will provide an even briefer summary of the main points of the Firth and Wagner (1997) article because that article has been reprinted in this issue. I will also point to the somewhat ambiguous position that the authors adopted: Were they calling for a more balanced approach to SLA or were they calling for a completely new one? Acknowledging this ambiguity is important because the reaction of the debate participants was shaped in part by how they interpreted Firth and Wagner's position. I will illustrate this point and fulfill my brief by discussing each commentary, which I will place into one of three categories: (a) broadly in agreement with Firth and Wagner (b) partially in agreement, and (c) mostly in disagreement. I will also summarize Firth and Wagner's (1998) response. 
I will then indicate why the reconciliation between those who agree and those who disagree is not likely, although I will offer one way of thinking that may help. I will conclude by stating what I take the impact of the debate to be, leaving it to Firth and Wagner (this issue) to offer their reflections on the current state of the field regarding these matters.

\section{A BRIEF GENEALOGY OF THE STUDY OF SECOND LANGUAGE ACQUISITION}

The modern-day study of second language acquisition, or SLA, as it came to be called, had its antecedents in the foundational texts published during the middle of the previous century, especially, Fries (1945), Lado (1957), Skinner (1957), and Weinreich (1953). These texts brought together a coherent theory of language (structural linguistics)and a theory of learning (behaviorist psychology), and reflected a renewed interest in language teaching and learning at the time. Two years after Skinner published his theory of operant conditioning, Chomsky (1959) countered with his scathing attack on behaviorism, and presented his own form of linguistics, which claimed that, at a deep level, all languages shared the same properties. In addition, Chomskyan linguistics introduced the notion that the developing language of the child was systematic from the start, due to the presence of an innate universal grammar and was not just a reflection of the linguistic input to which he or she had been exposed (Block, 2003; Selinker, 1972).

These claims were represented in the second language (L2) literature in a seminal article written by Corder (1967). Corder argued that language learners' errors were not a reflex of the native language (L1), but rather were reflective of the learners' underlying L2 competence. This perception was later extended in the claim that learners were actively involved in constructing a system out of the linguistic input to which they had been exposed, a linguistic system variously called an idiosyncratic dialect by Corder (1971), an approximative system by Nemser (1971), and an interlanguage by Selinker (1972). All three researchers highlighted the position that learners' language was a linguistic system in its own right, replete with forms that indicated that learners were applying cognitive strategies to the language learning task. These strategies resulted in, for example, overgeneralization errors, which were taken to be evidence of an attempt by learners to construct the rules of the target language. Furthermore, all three researchers adopted a target-language centered perspective (Sridhar, 1980), suggesting that the learners went through successive stages of learning, with the most advanced being the closest to the target language, usually taken to be the standard dialect of educated native speakers (NSs). Seeing learner language from this perspective led to an appreciation of the cognitive powers of language learners, an appreciation that was not present when language acquisition was seen to be a product of habit formation, as the behaviorists had been claiming in the years preceding the publication of Corder's article.

Another formative influence on SLA at the time was Brown's (1973) research on L1 acquisition. Brown was breaking new ground by showing that children learning English as their L1 exhibited a common order in their acquisition of certain grammatical morphemes. The Zeitgeist for this view was the cognitive revolution that was taking place in psychology and linguistics. The latter field was particularly influential in SLA, of course, in the form of Chomsky's (1965) declaration that the proper focus for the study of linguistics was the underlying homogeneous competence of the idealized speaker of the language. It was in competence, Chomsky proposed, that the systematicity and generativity of the underlying system could be observed. Subsequently, even though most SLA researchers did not choose to explain SLA in terms of Chomsky's universal grammar, they accepted the need to explain SLA in terms of the formation of a mental grammar. In keeping with Chomsky and U.S. structuralism, they also chose to conceive of progress in SLA as the accumulation of ever more complex linguistic structures and the increasing fluency in their use.

These developments in linguistics, psychology, and $\mathrm{L} 1$ acquisition research and the shift in awareness contributed by SLA pioneers led to the liberation of the field from the bondage of behaviorism. Language learners were seen as cognitive beings, much more actively involved in the construction of their L2 knowledge. Moreover, it was taken to be the researchers' mission to determine how learners accomplished the construction, which researchers did by pointing to the learners' use of formulaic utterances, hypothesis testing, rule formation, creative construction, learning strategies, and so on.

Owing to the pedigree of the SLA field, it was not surprising that a great deal of attention was given to the learners' developing morphosyntactic system. This attention was perhaps most obvious in early SLA research with the morpheme acquisition studies (Bailey, Madden, \& Krashen, 1974; Dulay \& Burt, 1973, 1974; Larsen-Freeman, 
1975, 1976a) and the discovery of developmental sequences (Milon, 1974; Ravem, 1974; Wode, 1976). Just as Firth and Wagner's (1997) article would do several decades later, this research galvanized the research community and attracted new researchers to the quest to understand SLA. I distinctly remember the excitement of researchers coming together at the Teachers of English to Speakers of Other Languages (TESOL) Convention in Denver in March 1974, at the Linguistic Society of America meeting at the University of Massachusetts in Amherst in the summer of 1974, and at the Sixth Annual Conference on Applied Linguistics in Ann Arbor in January 1975. Even in those early days, we believed that we were witnessing the birth of a new field-one that did not see language as behavior, one that no longer ignored the mind, one that put cognitivism squarely at the forefront of its explanations. As it turns out, it was a powerful birthright. It is fair to say that a cognitivist view has dominated the field ever since, leading Doughty and Long (2003) to characterize SLA primarily as a product of a cognitive faculty and the SLA field of the future "as a branch of cognitive science" (p. 4).

\section{FIRTH AND WAGNER'S CALL}

It was then approximately 30 years after the birth of a cognitively oriented approach to SLA that Firth and Wagner presented their 1996 paper, a work that called for an enlargement of the parameters of the field to include a social and contextual orientation to language. It is interesting that these authors were not the first to issue such a call. Indeed, those researchers (e.g., Frawley \& Lantolf, 1984, 1985; Lantolf \& Frawley, 1988) persuaded by the work of Vygotsky (1962) and other socially oriented researchers (Beebe, 1980; Norton Peirce, 1995; Tarone, 1983; Young, 1988) had been exploring and promoting the social dimension of SLA for some time. Moreover, Block (1996), Breen (1985), Crookes (1997), Rampton (1995), and van Lier (1994) among others, pointed critically to the essentially asocial view of much SLA research. I cannot, therefore, explain with any confidence the reception that Firth and Wagner received in their bid to do a similar thing. Perhaps it was the case, as with the Denver, Amherst, and Ann Arbor meetings that I alluded to earlier, that it was in the forming of a group-their coming together and finding each other-that made a difference.

Of course, the publication of the Firth and Wagner (1997) article in the MLJ and the responses of a theoretically eclectic group of researchers no doubt did much to propagate both the controversy and the social views that Firth and Wagner espoused. Contrary to popular opinion, it is not usually the case that lone researchers make discoveries in isolation. Research is very much a collective enterprise (Larsen-Freeman, 2000b). We give papers, read each others' work, come together at professional conferences, sometimes collaborate, and most of us at least benefit from having conversational partners to stimulate our thinking further. Theoretical shifts of the magnitude that Firth and Wagner were calling for presumably take a critical mass of like-minded researchers.

In any event, it is time to ask just what it was that so inspired the crowd that day in August 1996 and later inspired and incited the readers of the $M L J$. As I mentioned earlier, from my reading of Firth and Wagner (1997) and from my reading of several of the commentaries on their article, it seems to me that there was an ambiguity to their central position. Perhaps because of a political adroitness, these authors called for what at first blush appears to be a theoretically balanced approach to the study of SLA-one where both the social and the individual cognitive perspectives to SLA would receive attention. Two of the commentators agreed with this position (Kasper, 1997, and Poulisse, 1997), though each offered significant caveats. Indeed, some of the cognitively oriented researchers who took the greatest exception to the Firth and Wagner article also pointed out that they were themselves committed to looking at how (social) interaction was the source of modified input that could become intake in fueling the process of L2 acquisition (Gass, 1998; Long, 1997), allowing for social interaction to have at least an indirect influence on SLA. In addition, other SLA researchers had lent their voices to the same cause, that is, the need to look at both social and psychological influences on SLA (McKay \& Wong, 1996; Preston, 1996; Selinker \& Douglas, 1985; Tarone $\&$ Liu, 1995). Therefore, if what Firth and Wagner were calling for was a broadening of the field, perhaps such a broadening could have been accommodated without so much controversy.

However, in order to put forth their case for more representation for the social side, it appeared that Firth and Wagner (1997) were seeking to do more than redress a perceived imbalance. To this end, they urged SLA researchers to reconsider unquestioningly accepted and well-established concepts such as nonnative speaker (NNS), learner, and interlanguage. As Firth and Wagner stated in their 1998 response to the commentators, "we are unable to accept 
the premises of 'interlanguage'-namely, that language learning is a transitional process that has a distinct and visible end" (p. 91). Furthermore, these authors contended that, since its founding by Corder, SLA had been concerned with individual acquisition and its relation to languagespecific cognitive systems-the acquisition of L2 competence in the Chomskyan sense. "As such, it is flawed," they wrote, "and obviates insight into the nature of language, most centrally the language use of second or foreign language (S/FL) speakers" (Firth \& Wagner, 1997, p. 285). There was no ambivalence in these comments about the direction that they wished the SLA field to take. Challenging the foundational concepts of learner, nonnative speaker, and interlanguage, on which the field of SLA had been established some three decades earlier, seemed like a no-quarter assault. Hegemony can extend in either direction, of course, leaving little doubt in some researchers' minds that Firth and Wagner were making a bid for the supremacy of an entirely different approach to SLA.

As can be seen in the Firth and Wagner (1997) article, reprinted in this issue, Firth and Wagner find further faults as well. However, the allegation that mainstream SLA was fundamentally flawed owing to its individual cognitive focus clearly represents the most trenchant criticism. How then did the commentators respond? Those researchers/scholars who saw the call as one for achieving balance between psychological and social factors accepted it to some extent. Others strongly objected to the move to reposition the SLA field. Still others warmly embraced the call. I will begin by summarizing the commentaries of those that I place in this third group.

\section{COMMENTATORS IN SUPPORT OF FIRTH AND WAGNER'S CALL}

Hall (1997), not a new voice in the psychological-social debate, pointed out that the explananda in the two positions were very different. Where mainstream SLA (her term, which I adopt here) took as its explanandum the learning of decontextualized linguistic components, the new, socially oriented way examined learning not in terms of systemic knowledge, but rather in terms of the knowledge of, and the ability to use, language. Therefore, rather than talking about the acquisition of grammatical morphemes, she considered it more appropriate to look at such phenomena as the patterned ways that turns are taken in a conversation. As she wrote, the new (Firth \& Wagner, 1997) way of looking at SLA, a sociocultural way, "turns the process on its head" (p. 303). Rather than looking at SLA as the accumulation of linguistic structures, what is important "is the discursive routinization of our communication practices and the means by which we realize them" (p. 303). Adopting a Vygotskyan stance, Hall embraced Firth and Wagner's call to offer an explanation of language behavior and development that "originates in our socially constituted communicative practices” (p. 302). Furthermore, Hall argued that individual development cannot be considered apart from such practices, nor should the L2 learner be treated as "a deficient version of an idealized monolingual expert in linguistics" (p. 303). Casting no doubt on which of the two positions in Firth and Wagner she believed, Hall asserted that the new view called for a radical reconceptualization of the SLA field and that "many of its presuppositions on language and learning are incommensurable with those of the more mainstream position" (p. 305).

Also adopting the stronger of the two positions present in Firth and Wagner (1997), Liddicoat (1997) began his commentary by discussing the imbalance that existed between their social, contextualized view of SLA and the mainstream view of SLA as a relatively context-free cognitive phenomenon. However, after pointing to the imbalance, he left little doubt that he subscribed to the more radical stance present in Firth and Wagner, that is, the need to reconceptualize the field. Liddicoat maintained that whereas traditional SLA research focused more on the learner's ability to produce morphosyntactic units, what should be in focus is the learner's ability to use language to create a message. A helpful elaboration on the difference between these foci is Liddicoat's observation that rather than focusing on what a learner cannot yet do, SLA researchers should attend to what a learner can do with the available resources.

For Liddicoat (1997), the other big shift that accompanied the newer perspective was the need to consider a different research methodology. Rather than investigating the macrolevel concepts of NS and NNS or learner, it would be better, according to Liddicoat, if microlevel investigations took place, investigations that would study "the actual social relationships that are being achieved through the talk in progress" (p. 314). He offered his reasoning: "this preoccupation with macro-level categories-in particular with the participant as a learner-has led to actual use of language being relegated to a secondary place behind the identification of the processes involved in the activity of learning” (p. 314).

Illustrating the problem that comes from ignoring language use, Liddicoat (1997) discussed 
the fact that in mainstream SLA investigations of NS-NNS interaction, it was always the former who asked the questions. Liddicoat hypothesized that this pattern may have come about as a result of such interactions typically taking the form of an interview, where one of the two interlocutors was quite naturally the questioner. The interviewer role was normally assumed by the NS because the purpose of the interactions in the research studies was to elicit data from NNSs. For this reason, the data were skewed, leading Liddicoat to conclude that it was important not only to look at interlocutors' respective roles, but also at the purpose of the talk/interaction.

Rampton (1997) also adopted Firth and Wagner's (1997) radical position in the debate, alleging that the mainstream SLA use of the notions of linguistic competence and speech community belonging are fundamentally flawed. Rampton wrote "certainly, sociolinguists show that individuals often belong in more than one speech community, that a single speech community often has more than one language, and that each language is itself variable" (p. 329).

Rampton's (1997) displeasure with mainstream SLA research was also grounded in the critical philosophical stance he adopted. Rampton challenged modernist notions inherent in mainstream SLA, such as the search for "universals, referential above indexical meaning, disembedded cognition, value-free inquiry, progress as a natural condition, and assimilation to the norms of an idealized monolingual U.K. or U.S. national" (p. 330). Instead, he pointed to the postmodern preoccupation with hybridity-being neither on the inside nor on the outside of a particular social group and "the key imperative of our time" which is "to learn to live with difference" (p. 330). With this postmodern sociological orientation, Rampton asserted that there are "now more scholars interested in how people negotiate and reconcile themselves both to otherness and incompetence" (p. 330). In accord with Liddicoat (1997), Rampton observed that researchers need to be looking at how people get by with what they can do in language, rather than what they cannot do.

Rampton (1997) also pointed to SLA researchers' choice to align themselves with natural sciences in order to establish the seriousness of their enterprise. This alignment explains SLA's models of inquiry and methodological choices. However, he asserted that when confronted with fluidity in linguistic situations, such as the study of pidgins and creoles, researchers needed to rethink their methodology. It would be helpful in this regard, Rampton thought, for SLA re- searchers to study the heterogeneous linguistic situations that exist outside the classroom, such as lingua franca negotiations between NNSs and the diaspora of Black English vernaculars, because "these are varieties that one really can not start to analyse with preconceived ideas about native speakers and well-formed languages" (p. 332).

\section{COMMENTATORS IN PARTIAL AGREEMENT WITH FIRTH AND WAGNER'S CALL}

The second category of respondents is made up of those who partially agreed with Firth and Wagner (1997). Into this group, I place the commentaries of Kasper (1997) and of Poulisse (1997) because both agreed on the desirability of broadening the perspective although still affirming a significant or primary role for cognition in SLA.

Kasper (1997) acknowledged that the constructs of learner and NNS are "highly reductionist in that they abstract from the complex multiple identities that constitute real people" (p. 309). Nonetheless, as she observed, everyone does it: "Of course, all social sciences ... construct their idealized agents by reducing away what seems trivial in terms of the adopted theory" (p. 309). For this reason, Kasper added that "I am not too concerned that generic terms such as 'learner' and 'nonnative speaker' suggest to anybody that all learners or all nonnative speakers are the same. What they do suggest is a researcher's focus on human agents" (p. 309).

Kasper (1997) warned against the comparative fallacy, however, in which L2 learner performance is compared with that of NSs, and therefore seen to be deficient. In addition, she asked the important question, "who should learners be compared with? The solution to the comparative fallacy does not renounce on comparison but selects more appropriate baselines" (p. 310). "For instance," Kasper maintained, "when you study the phonological development and ultimate attainment of Anglocanadians learning French, do not choose as a baseline monolingual speakers of Canadian French; choose highly competent French-English bilinguals" (p. 310) instead.

Kasper also concurred with conversation analysts (CA) Liddicoat (1997) and Firth and Wagner (1997) in believing it important "to demonstrate how social order is constructed at the microlevel of conversational interaction" (p. 308); however, she added that "we should transcribe adequately to the research purpose at hand. CA conventions have no inherent superiority over other notation systems" (p. 309). 
A very important point that Kasper (1997) called "the most nagging problem" with the Firth and Wagner (1997) article is that it

purports to redirect the field of SLA, but has in fact very little to say about L2 acquisition. Any theory of language acquisition has to make explicit what the conditions and mechanisms of learning are. In other words, it has to address the question of how learners' interlanguage knowledge progresses from stage A to stage B, and what events promote or hinder such progress. Firth and Wagner do not address these questions. What they seem to call for are socially situated studies of second language use. (p. 310)

It is here where Kasper (1997) staked out her balanced position most clearly. Although she had long been interested in issues of pragmatics, sociolinguistics, and discourse analysis, she firmly believed that SLA was about establishing new knowledge structures and making them available subsequently, and for this reason, "A noncognitivist discipline that has learning as its central object is a contradiction in terms" (p. 310). Nevertheless, she indicated that because SLA takes place in a social context, the context must affect the SLA process.

Furthermore, because language learners are not passive recipients of input but actively participate in different kinds of interaction, they also construct their own identities and those of their respective others; these experiences are likely to be reflected in different parts of learners' developing L2 competence. (pp. 310-311)

Also apparently interpreting Firth and Wagner's (1997) call as one of seeking balance, Poulisse (1997) agreed that developing linguistic competence involved both acquiring the system and its use. However, Poulisse added that

I would consider the psycholinguistic approach to be primary though, and the sociolinguistic approach to be secondary. You first need to describe the basic processes of learning and using language, and then to discuss the contextual factors that may influence these processes. (p. 324)

Summarizing in this way, Poulisse wrote, "Irrespective of one's research paradigm," it seems useful to search for universal and underlying features of language processes (p. 325).

\section{COMMENTATORS OPPOSED TO FIRTH AND WAGNER'S CALL}

In this third category, I place commentators who seemed to take the greatest exception to
Firth and Wagner's (1997) call. Even these commentators, though, acknowledged the merit of a social perspective. For instance, Long (1997) allowed that Firth and Wagner were probably "perfectly justified and probably right in arguing that a broader, context-sensitive, participant-sensitive, generally sociolinguistic orientation might prove beneficial for SLA research" (p. 322). However, Long pointed out that it is incumbent upon the challengers not just to assert the benefits, but to demonstrate empirically that social contextual factors are relevant, and that while attempting to do so, Firth and Wagner needed to show "how they plan to deal with some obvious methodological problems" (p. 322). Along similar lines, Long accepted the possibility that mainstream SLA research underestimated the impact of NNS social identities but left it to research to determine if this was so.

More important, Long (1997) and Kasper (1997) were united in their belief that, although L2 acquisition occurs through participation in conversation, SLA is centrally about acquisition, not use. Indeed, Long underscored this point by asserting that "most SLA researchers view the object of SLA inquiry as in large part an internal, mental process: the acquisition of new (linguistic) knowledge" (p. 319). Furthermore,

the goal of research on SLA, qualitative or quantitative, inside or outside the classroom, in the laboratory or on the street, is to understand how changes in that internal mental state are achieved, why they cease (so-called "fossilization") and which learner, linguistic and social factors (and, where relevant, which instructional practices) affect and effect the process. (p. 319)

Besides clarifying the goal of mainstream SLA, Long (1997) made the very important point, also concurring with Kasper (1997), that some form of mental representation of the L2 must exist or how else could it be explained that

the result of a communicative experience or input does not evaporate when the learner leaves the room or when the learner goes to sleep at night; it remains, memory permitting, in the form of a modified, individual, partly idiosyncratic, internal mental representation of the L2. (p. 319)

Two issues of the $M L J$ later (Spring, 1998), a further commentary and a response from Firth and Wagner (1998) were published. In the first, Gass (1998) voiced an equally strong reaction to their call. First of all, Gass objected to Firth and Wagner's (1997) characterization of her work as 
being about interactional and sociolinguistic dimensions of language because, as she stated,

the goal of my work (and the work of others within the input/interaction framework...) has never been to understand language use per se, but rather to understand what types of interaction might bring about what types of changes in linguistic knowledge. (p. 84)

Thus, Gass reprised the important theme present in Kasper and Long's commentaries that language use is not acquisition. She punctuated this point by noting that the crucial question is "how do people learn a L2-The question is not: How do people use a $L 2$, unless the latter question is a means of getting at the former" (p. 85). Furthermore, "the emphasis on input and interaction studies is on the language used and not the act of communication" (p. 84).

Gass (1998) also clarified the use of NS data as baseline data against which progress in the $\mathrm{L} 2$ was measured.

It is not so much that NS interaction is the 'norm,' if by that is meant that NNSs are involved in something subnormal or abnormal. The point is that baseline data reflect data from those who are not involved in learning. The crucial variable is the presence or absence of learning. (p. 86)

Finally, Gass (1998) concluded on a somewhat more conciliatory note:

Views of language that consider language as a social phenomenon and views of language that consider language to reside in the individual do not necessarily have to be incompatible. It may be the case that some parts of language are constructed socially, but that does not necessarily mean that we cannot investigate language as an abstract entity that resides in the individual. Further, as many have argued, there are parts of what we know about language (e.g., what is grammatical and what is ungrammatical) that cannot come from social interaction. The establishment of a rigid dichotomy ... is perhaps misguided. (p. 88)

\section{FIRTH AND WAGNER'S 1998 RESPONSE}

In response to these commentaries, Firth and Wagner (1998) restated their belief that the field of SLA was in need of conceptual and methodological broadening; however, they acknowledged that Long (1997) and Kasper (1997) were right to point out the centrality of acquisition. They maintained, though, that the notion of acquisition is not clearly defined and that it is very difficult to pinpoint where use ends and acquisition begins.
Firth and Wagner felt it was important, therefore, for researchers to deconstruct the dichotomy of use versus acquisition. They concluded that the notion of competence is obsolete because one simply cannot unproblematically separate performance from competence. Moreover, they argued, by discounting language use, mainstream SLA researchers erected barriers between themselves and those who adopted a more sociolinguistic perspective.

Firth and Wagner (1998) also argued for a more emic view of communication. "Communication is not simply transfer of information in a 'normal,' that is, native-speaker-equivalent, manner. What may appear 'abnormal' to observer-analysts may be regarded as appropriate and 'normal' by the interactants themselves" (p. 93).

As for methodological implications, Firth and Wagner (1998) remained convinced of the need to collect data from naturally occurring everyday or workplace interactions between speakers of different languages rather than relying on experimental elicited data, which they said mainstream SLA researchers had used. Finally, they asserted that "a 'functionalist' model of language, firmly rooted in contingent, situated, and interactionist experiences of the individual as a social being, is better suited to understand language and language acquisition ... than a structural model" (p. 92).

\section{COMPARING THE TWO POSITIONS}

From the brief summary of the commentaries and of Firth and Wagner's (1998) response that I have provided, it should be clear that one view cannot readily accommodate the other. I summarize the two positions in Table 1 in order to underscore this point. For ease of comparison, I have adopted the heuristic of a binary contrast. Of course, displaying the differences in a binary form obscures any overlap or agreement between them and represents the way that I perceive the contrast, one that may not be shared by all authors. $^{1}$

At this point, several observations can be made from reviewing the two positions as summarized in Table 1. First, when reading down the columns, it can be seen that each view is internally consistent. For instance, if you take language to be a mental construct and learning to be a change in a mental state, then it makes sense to seek cognitive explanations. However, if you see language as a social construct and learning as involving a 
TABLE 1

Cognitivist and Social Views of SLA Contrasted

Cognitivist SLA (Mainstream)

Social SLA (Challenger)

1. Role of Context

2. Nature of Language

3. Nature of Learning

4. Primary Research Focus

5. Objects of Inquiry in Language-Focused Research

6. Identity of Research Participants

\section{Perspective on Evaluating Learners' Progress}

\section{End State}

\section{Philosophical Orientation}

10. Research Site

\section{Primary Level of Research Conceptualizations}

12. Attitudes Toward Acceptance of SLA Theories
Social context is the site in which L2 acquisition takes place; however, if you change the context, the acquisition process remains the same. The goal is to search for universals that transcend individual contexts.

Language is a mental construct.

Change in mental state

The primary focus is on language acquisition (how people learn a language, not how they use it). Given this focus, what is important are cognitive factors of knowledge representation, processing, and recall.

What is of interest is the aggregation and increasing complexity and control of linguistic structures by learners.

The salient identity of the participant in a research study is that of a learner.

Progress is measured by where along the route toward target proficiency the learner is as indicated by the learner's linguistic performance.

The end state occurs when learner language and target language are congruent or where learner language is stabilized/fossilized.

Scientific, value-free inquiry

Modernist

Varied, sometimes natural environments, sometimes experimental, where data are elicited

Macrolevel idealizations, in other words, native speaker, learner

One theory will prevail; empiricism will determine which.

Positivist
Social context influences performance. Social factors are related to systematic variation in learner language. Each context is unique although certain generalizations, such as turn-taking principles or observations about repair, can be made.

Language is a social construct.

Change in social participation

The primary focus is on language use. Language use and acquisition cannot be easily separated. Therefore, what is important are social/interactional factors and their effect on the language used.

What is of interest are discursive routines of communication processes. There is also a need to look at the purpose of talk; a functional perspective to language is most helpful.

The identity that the research participant adopts makes a huge difference, and it may not be that of learner. For example, in the moment, a learner may not "perform his or her competence" because he or she might want to align socially with another less competent peer.

What is at issue is what the learner does with the resources that are available. Look at what the learner does to get his or her message across, not what the learner cannot do.

There is no end state.

\section{A critical view}

Postmodernist

Varied contexts where language is used naturally and heterogeneously

Microlevel social relationships that are being achieved through talk in progress

Multiple theories are welcome, even necessary.

Relativist; pluralist 
change in social participation, then focusing on language use factors is consistent.

Second, it is clear that in some way both positions are correct. For example, if you accept a structural view of language, as mainstream SLA researchers do, then it could be true that learner performance remains unchanged as learners move from one context to the other (Tarone \& Liu's, 1995, research notwithstanding). For instance, in pursuit of an explanation for the English morpheme acquisition orders that early SLA researchers were reporting, I compared the frequency with which teachers in English as a second language (ESL) classrooms were using common grammatical morphemes with that of English-speaking parents speaking to their children acquiring English as their L1. I found that the frequency ranks were significantly positively correlated (Larsen-Freeman, 1976b), presumably because of the ubiquity of these structural elements. However, if you are interested in interactional phenomena, performance may well differ due to social context. It is well known, for instance, that natural use conditions favor self-repair (Schlegloff, Jefferson, \& Sacks, 1977), whereas classroom language use favors other repair, usually by the teacher (Schwartz, 1977).

Perhaps the most obvious observation of all to be made from an examination of Table 1 is that researchers do not focus on the same data or ask the same questions. Whereas the cognitivists look to see how linguistic structures are manifest in learners' performance and how learners' performance becomes increasingly accurate, complex, and fluent, socially oriented researchers wish to study instead how language resources are deployed in social situations and how participation changes. Fundamental questions such as: Is the social context a site for a cognitive process or is it that the social context fundamentally shapes and alters the cognitive process? have not been resolved by either side. In this way, the two viewpoints really exist in parallel worlds (Zuengler \& Miller, 2006), with minimal overlap between them. Having such fundamental ontological and epistemological differences has meant that they have not influenced each other very much.

Invoking Sfard's (1998) distinction between acquisition and participation metaphors, I stated the following in 2002:

the acquisition/use division is ontological in nature, with the two positions reflecting fundamental differences in the way they frame their understanding of learning. Those that operate within an acquisition metaphor study the language acquisition of individu- als and evidence of an individual's success is sought in the acquisition of target rules and structures. Those that operate within a participation metaphor study the language use of socially constituted individuals within groups, and seek evidence of success in the learners becoming participants in the discourse of the community. Distinguishing the mainstream and the challenger views in this way is more illuminating than construing the dispute solely as a psycholinguistic versus sociolinguistic split. It is, at the same time, more problematic, for it is far less obvious how such a fundamental difference can be resolved. (LarsenFreeman, 2002, p. 37)

\section{RECONCILING THE DIFFERENCES}

The fact that there are competing views in SLA is not remarkable. Indeed, some would find it a very healthy sign (Lantolf, 1996). Moreover, it may be the case that the two positions contrasted above are simply focusing on different aspects of a common problem. In support of this point, Wagner (2004) observed that the Firth and Wagner (1997) claim was not that there are no inner mental states involved in language acquisition; it is simply that, for socially oriented researchers, increasing participation in social life is the main object of description of a social theory of learning. One option, therefore, is for each side to pursue its own research agenda, each accounting for a different dimension and each providing the necessary checks and balances in preventing hegemony in either direction.

Indeed, this option has already been exercised to some extent. Whereas the two positions may have once competed for "air time," now it seems that there is a bifurcation in the field, with each side holding its own conferences, or at least holding its own dedicated colloquia within conferences, publishing in journals that favor its point of view, ${ }^{2}$ and so on. Thus, as Ortega (2005) put it, "views of SLA as a basic science that investigates an aspect of human cognition without regard for knowledge use ... co-exist with views of SLA as inquiry about human capacities that are socially and politically embedded" (pp. 318-319). Co-existence does not necessarily mean ignoring the other's position. Thus, one consequence of the Firth and Wagner (1997) article, it seems to me, is that the challenger's view must now be reckoned with (see, e.g., Long, 2007).

A second option for dealing with the dispute is to have it adjudicated through empiricism. Long (1997) made this point plainly: "simply asserting that ... a greater 'balance' between cognitive and other 'more holistic' social views is needed, as Firth and Wagner do, will not make it so" 
(p. 319). Earlier, Eckman (1994) suggested that the relationship between psycholinguistic and sociolinguistic factors in SLA is one that needed to be determined by empirical means, not by arguments alone. However, as Tarone (2000) noted,

neither strand of SLA research has consistently and systematically set out to gather the sort of data which might show whether social factors affect cognitive processes of acquisition in specific ways and thereby enable both strands to see how their work is related. (p. 186)

To remedy this situation, Tarone (2000) suggested a research agenda that might help in seeing how the two sides are related, a point that Gass (1998) also suggested would be useful. Tarone posed two questions: (a) "If two L2 learners acquire English in two different social settings, will those learners internalize two different interlanguage (IL) grammars?" (p. 187), and (b) What happens if you "change the social setting altogether? Will the way that the learner acquires the L2 change much?” (p. 190). Tarone's answer to the first question was affirmative, and her explanation was that the different grammars are due to the fact that learners receive different target language input in different contexts. Her answer to the second question was also affirmative, though limited to research findings pointing to changes in error correction, developmental sequences, and the negotiation of meaning. In answer to both questions, it should be noted, Tarone adhered, for the most part, to the mainstream definition of the explanandum, that is, linguistic structures. ${ }^{3}$ An attempt that does not adhere to the mainstream definition, but that seeks to bring the different positions together, can be found in calls to use CA longitudinally, accompanied by attempts to investigate how learners actively use the microstructure of interactional language as a resource for acquisition (Markee \& Kasper, 2004).

These approaches appear to hold promise. At least they are an attempt to go beyond the polemical debate sparked by Firth and Wagner (1997). However, it is important to remember that, to some extent, answers to questions such as Tarone's (2000) depend on what you are looking for. If you are looking for the ways that context affects different repair strategies, which in turn affect learning, then it is likely that you will find them. However, as I indicated earlier, if you are looking at the frequency of use of common grammatical morphemes, then perhaps you will not. As Sfard (1998) warned, "empirical evidence is unlikely to serve as an effective weapon in paradigm wars" (p. 12) because the power of data to determine who is right may be confined to the paradigm within which they came into being.

Thus, although I am encouraged by the newer research agendas, it may make sense to pursue another response to Firth and Wagner's (1997) challenge, as well. In addition to co-existence and empiricism to resolve differences, there is a third option, one to which the field of SLA has historically resorted. As I have written earlier:

When faced with challenges to prevailing views in the past, the field of SLA has not replaced a view with its challenger, but rather has repeatedly broadened its domain of inquiry (Larsen-Freeman \& Long, 1991). When fault was found with the a priori contrastive analysis hypothesis, a view of learning was posited that aimed to explain the SLA process through an analysis of learner errors, appealing to contrastive analysis to account for some of them. In turn, error analysis was encompassed by a view that held that only a complete analysis of the learners' performance, including their errors, would suffice. Performance analysis was subsumed by discourse analysis when it became evident that attention needed to be paid not only to learners' performance, but also to what sorts of interaction they engaged in. (Larsen-Freeman, 2002, p. 38)

Thus, with a nod to our history, I suggest that the way out of the acquisition versus use dilemma is to find a larger lens with which to examine issues in our field. Furthermore, I have recommended one such lens-chaos/complexity theory (LarsenFreeman, 1997, 2000a, 2002, 2003, 2006, 2007a; Larsen-Freeman \& Cameron, in press) - not as a new overarching theory, but as another way of reframing the search for understanding.

Chaos/complexity theory is an ecological theory (Kramsch, 2002) that concerns the study of complex, dynamic, nonlinear, self-organizing, and adaptive systems (Larsen-Freeman, 1997). Although not conceived to deal with issues of concern to SLA researchers, it has the power to inform them, especially in helping to unify the many dichotomies that SLA researchers have adopted, such as the one relevant to this issue of the $M L J$, that is, the separation of the use of language from its mental structure. From an ecological perspective, the world is not composed of static forms, stable objectified entities. Instead, change and adaptation are continuous in the world and the phenomena that comprise it, and any perceived stability emerges from the dynamics of the system. The fact is that language forms are being continually transformed by use (Bybee, 2006). As such, any linguistic representation in the learner's mind is strongly tied to the experience that a speaker has had with language and may bear little 
resemblance to forms that NSs employ or that fit linguists' categories.

When we entertain a view of language in a less mechanistic and more organic way, as a complex adaptive system, we recognize that every use of language changes the language resources of the learner/user, and the changed resources are then potentially available for the next speech event. "The act of playing the game has a way of changing the rules," as Gleick (1987, p. 24) stated in describing naturally occurring complex adaptive systems. One of the insights gained from applying a more dynamic way of looking at language and its development, therefore, is to see that real-time language processing, developmental change in learner language, and evolutionary change in language are all reflections of the same dynamic process of language usage (see, e.g., Bybee, 2006; Larsen-Freeman, 2003; Smith $\&$ Thelen, 1993). These processes are not sequential, but rather they occur simultaneously, albeit at different timescales. It is not that you learn something and then you use it; neither is it that you use something and then you learn it. Instead, it is in the using that you learn-they are inseparable.

The natural state of the linguistic system can then be "defined as a dynamic adaptedness to a specific context" (Tucker \& Hirsch-Pasek, 1993, p. 362), in which the context itself is being transformed by volitional language users/learners. The context does not mean only the physical space. It includes the intersubjective space between interlocutors, among other things. Humans "softly-assemble" (Smith \& Thelen, 1993, p. 3) or adapt their language resources to meet their specific present goals-a make-do extemporaneous response to the communicative pressures at hand. Adapting their resources sometimes means appropriating extant constructions (Goldberg, 1995; Tomasello, 2000); at other times, it means innovating by analogy or recombination. However, the constructions themselves are not limited to units from linguistic theories, nor are they a priori social constructs. Instead, the language resources themselves are a hugely variegated lot, likely best accounted for from an emic perspective.

The shape of language is surely affected by limitations of human perception and cognitive processing and all the attendant adaptations that processing has meant for language, such as its evolving a fractal or scale-free geometry (LarsenFreeman, 1997; Larsen-Freeman \& Cameron, in press) to facilitate its learning. Evidence that language is social in nature stems from the fact that it is used for social action within a context of language use (Atkinson, 2002), where pressures and affordances, learners' identities, goals and affective states all have a profound effect on language performance (Cameron \& Deignan, 2006; van Lier, 2004).

In short, viewing language as a complex adaptive system makes us regard linguistic signs not as "autonomous objects of any kind, either social or psychological," but as "contextualized products of the integration of various activities by [particular] individuals in particular communicative situations" (Harris, 1993, p. 311). It logically follows that they are continually created to meet new needs and circumstances" (Toolan, 2003, p. 125). The patterns are "created and dissolved as tasks and environments change" (Thelen \& Bates, 2003 , p. 381). Some patterns are preferred; others are more ephemeral. The preferred ones become stabilized through frequency of use and the strengthening of connection weights in neural networks. Thus, developmental change seems "not so much the stage-like progression of new accomplishments as the waxing and waning of patterns, some stable and adaptive and others fleeting and seen only under special conditions" (Thelen \& Bates, 2003, p. 380). In this way, it can be said that the learning of language is never complete (Larsen-Freeman, 2005). Furthermore, there is no homogeneity. We create linguistic forms (by combining and analogizing constructions) when we want to make new meanings—we go beyond the input (Larsen-Freeman, 1997).

Because changes in the system are engendered by agents' adaptation to their environment (van Lier, 2004), based on their previous languageusing history, both social (learners' roles and relationships, with whom they identify, how they deploy their agency, the amount and type of mediation that occurs, etc.) and cognitive (the attentional resources brought to bear, the perceptual salience of forms used, their probabilistic frequency, the limitations of short-term memory, etc.) factors are all potentially relevant. However, it is by no means sufficient to show how such factors affect the use of language at the moment. There are already many studies that show, for instance, how social factors affect interlanguage use at a single given time (e.g., Tarone, 2000). Any definition of learning must involve the transcendence of a particular time and space. It must show how the changed resources are henceforth available. As Long (1997) said, they do not just "evaporate" (p. 319). What it is that gets carried over in time and space, of course, is an open question.

From a chaos/complexity theory point of view, what endures is not a rule-based competence, but a structured network of dynamic 
language-using patterns, stored in memory (Ellis \& Larsen-Freeman, 2006; Larsen-Freeman, 2007b) with specific information about instances of use retained in the representation. Because these variegated language-using patterns emerge from language use, they are not only characterized by linguistic features, but they are also sometimes accompanied by gesture, unique prosodics, and by affective, cognitive, and episodic associations, experienced as they are embedded in a sociohistorical context. Thus, an individual's perceptual, conceptual, and linguistic systems are continually being updated by that part of the context that the individual perceives in the same way that infants' perceptual, conceptual, and enactive systems are not simply innate, but tuned through the sociocultural world in which they live (Gibson, as cited in Reed \& Jones 1982; Watson-Gegeo \& Nielsen, 2003). Experience shapes our neural networks (Watson-Gegeo, 2004). Connectionist models, with their multiply connected networks, parallel distributed processing, and learning as the strengthening of connections through frequency, capture the essential relationship between cognitive development and social experience (Watson-Gegeo \& Nielsen, 2003).

Indeed, new work in chaos/complexity theory, dynamic systems theory, connectionism, emergentism, and language usage studies is making remarkable headway in transforming the way we think about language and its learning. A chaos/complexity theory perspective does not reconcile all the differences that I listed in Table 1, but it suggests that the acquisition/use dichotomy can usefully be deconstructed, and it provides a larger container within which to study the complex, dynamic process of SLA.

When I was asked several years ago to comment in this journal on the usefulness of CA for L2 acquisition research, I answered "It all depends."

Saying that something has been learned, saying what has been learned, when it has been learned, and the reason it has been learned are big challenges for all SLA researchers, cognitivists as well as those who practice CA. ... There is no anointing in our discipline-it takes a demonstration of the usefulness of the perspective in producing new insights into learning so that sufficient numbers of others want to join in the work. (Larsen-Freeman, 2004, pp. 606-607)

I myself am less drawn to an acceptance of parallel worlds and more to understanding where the two perspectives intersect. I say this not in an attempt to eliminate internecine feuding, but rather in recognition of the fact that our field is beset by dialectics: learning versus use, psychological versus social, acquisition versus participation, and yet, it is focusing on the dynamic coupling of each pair that is likely to be the most productive. Of course, once again, it should be said that asserting this to be the case is inadequate. Any new way of looking at language acquisition will not take root by pronouncement. What we should be seeking, it seems to me, is not to maintain old walls, or to construct new ones, but instead to open up new spaces (Watson-Gegeo, 2004). Happily, these days, more and more researchers are taking up the challenge of researching language acquisition and use from a sociocognitive perspective (see, e.g., Atkinson, 2002; Atkinson, Churchill, Nishino, \& Okada, 2007; de Bot, Lowie, \& Verspoor, 2007; Ellis \& Larsen-Freeman, 2006; Larsen-Freeman \& Cameron, in press). I find evidence that a new critical mass is emerging, and in keeping with our history, I anticipate that the field of inquiry will once again broaden and move on.

\section{NOTES}

${ }^{1}$ I should also point out that in Table 1 and the discussion of it, I use examples from morphosyntax to illustrate the cognitive focus on linguistic structures and examples from conversational structure to illustrate the social view. I do this because of the theoretical commitments of most of the authors in the articles I discuss. However, by favoring morphosyntax, I do not mean to exclude the studies of the acquisition of phonology and the lexicon that have cognitive underpinnings, nor do I mean to ignore all the work on the social dimensions of language, such as the study of the acquisition of speech events and speech acts and genres or the work of socioculturalists, language socialization researchers, and others who share with conversational analysts a social perspective on language use and acquisition.

${ }^{2}$ For example, it is my impression that the Second Language Research Forum has attracted either cognitively oriented or socially oriented researchers over the past few years, depending on the theme of the conference set by the convener. Also, to cite another example, SLA researchers operating from a universal grammar perspective tend to publish the results of their research in the journal Second Language Research.

${ }^{3}$ Swain, another prominent SLA researcher, has also embraced a more social view of the learning process, while still attempting to account for the same explanadum, that is, linguistic structures (Swain, 2000).

\section{REFERENCES}

Atkinson, D. (2002). Toward a sociocognitive approach to second language acquisition. Modern Language Journal, 86, 525-545.

Atkinson, D., Churchill, E., Nishino, T., and Okada, H. (2007). Alignment and interaction in a 
sociocognitive approach to second language ac quisition. Modern Language Journal, 91, 169-188.

Bailey, N., Madden, C., \& Krashen, S. (1974). Is there a "natural sequence" in adult second language learning? Language Learning, 21, 235-243.

Beebe, L. (1980). Sociolinguistic variation and style shifting in second language acquisition. Language Learning, 30, 443-447.

Block, D. (1996). Not so fast! Some thoughts on theory culling, relativism, accepted findings and the heart and soul of SLA. Applied Linguistics, 17, 65-83.

Block, D. (2003). The social turn in second language acquisition. Edinburgh, UK: Edinburgh University Press.

Breen, M. (1985). The social context for language learning: A neglected situation? Studies in Second Language Acquisition, 7, 135-158.

Brown, R. (1973). A first language. Cambridge, MA: Harvard University Press.

Bybee, J. (2006). From usage to grammar: The mind's response to repetition. Language, 82, 711-733.

Cameron, L., \& Deignan, A. (2006). The emergence of metaphor in discourse. Applied Linguistics, 27, 671-690.

Chomsky, N. (1959). A review of B. F. Skinner's Verbal behavior. Language, 35, 26-58.

Chomsky, N. (1965). Aspects of the theory of syntax. Cambridge, MA: MIT Press.

Corder, S. P. (1967). The significance of learner's errors. International Review of Applied Linguistics, 5, 161170.

Corder, S. P. (1971). Idiosyncratic dialects and error analysis. International Review of Applied Linguistics, 9, 147-159.

Crookes, G. (1997). SLA and second language pedagogy: A socioeducational perspective. Studies in Second Language Acquisition, 19, 93-116.

de Bot, K., Lowie, W., \& Verspoor, M. (2007). A dynamic systems approach to second language acquisition. Bilingualism: Language and Cognition, 10, 7-21.

Doughty, C. J., \& Long, M. H. (Eds.). (2003). The handbook of second language acquisition. Malden, MA: Blackwell.

Dulay, H., \& Burt. M. (1973). Should we teach children syntax? Language Learning, 23, 245-258.

Dulay, H., \& Burt, M. (1974). Natural sequences in child second language acquisition. Language Learning, 24, 37-53.

Eckman, F. (1994). The competence-performance issue in second-language acquisition theory: A debate. In E. Tarone, S. Gass, \& A. Cohen (Eds.), Research methodology in second-language acquisition (pp. 315). Hillsdale, NJ: Erlbaum.

Ellis, N., \& Larsen-Freeman, D. (2006). Language emergence: Implications for applied linguisticsIntroduction to the special issue. Applied Linguistics, 27, 558-589.

Firth, A., \& Wagner, J. (1997). On discourse, communication, and (some) fundamental concepts in SLA research. Modern Language Journal, 81, 285300 .
Firth, A., \& Wagner, J. (1998). SLA property: No trespassing! Modern Language Journal, 82, 91-94.

Frawley, W., \& Lantolf, J. (1984). Speaking as self-order: A critique of orthodox L2 research. Studies in Second Language Acquisition, 6, 143-159.

Frawley, W., \& Lantolf, J. (1985). Second language discourse: A Vygotskyan perspective. Applied Linguistics, 6, 19-44.

Fries, C. C. (1945). Teaching and learning English as a foreign language. Ann Arbor: University of Michigan Press.

Gass, S. (1998). Apples and oranges: Or, why apples are not orange and don't need to be. Modern Language Journal, 82, 83-90.

Gleick, J. (1987). Chaos: Making a new science. New York: Penguin Books.

Goldberg, A. (1995). Constructions: A construction grammar approach to argument structure. Chicago: University of Chicago Press.

Hall, J. K. (1997). A consideration of SLA as a theory of practice: A response to Firth and Wagner. Modern Language Journal, 81, 301-306.

Kasper, G. (1997). "A" stands for acquisition: A response to Firth and Wagner. Modern Language Journal, 81, 307-312.

Kramsch, C. (Ed.). (2002). Language acquisition and language socialization: Ecological perspectives. London: Continuum.

Lado, R. (1957). Linguistics across cultures. Ann Arbor: University of Michigan Press.

Lantolf, J. (1996). SLA theory building: "Letting all the flowers bloom." Language Learning, 46, 713-749.

Lantolf, J., \& Frawley, W. (1988). Proficiency: Understanding the construct. Studies in Second Language Acquisition, 10, 181-195.

Larsen-Freeman, D. (1975). The acquisition of grammatical morphemes by adult ESL students. TESOL Quarterly, 9, 409-430.

Larsen-Freeman, D. (1976a). An explanation for the morpheme acquisition order of second language learners. Language Learning, 26, 125-134.

Larsen-Freeman, D. (1976b). Teacher speech as input to the ESL learner. UCLA Workpapers in TESL, 10, 45-49.

Larsen-Freeman, D. (1997). Chaos/complexity science and second language acquisition. Applied Linguistics, 18, 141-165.

Larsen-Freeman, D. (2000a). Second language acquisition and applied linguistics. Annual Review of Applied Linguistics, 20, 165-181.

Larsen-Freeman, D. (2000b). An attitude of inquiry: TESOL as science. The Journal of the Imagination in Language Learning, 5, 18-21.

Larsen-Freeman, D. (2002). Language acquisition and language use from a chaos/complexity theory perspective. In C. Kramsch (Ed.), Language acquisition and language socialization (pp. 33-46). London: Continuum.

Larsen-Freeman, D. (2003). Teaching language: From grammar to grammaring. Boston: Heinle/Thomson. 
Larsen-Freeman, D. (2004). CA for SLA? It all depends. Modern Language Journal, 88, 603-607.

Larsen-Freeman, D. (2005). Second language acquisition and the issue of fossilization: There is no end, and there is no state. In Z.-H. Han \& T. Odlin (Eds.), Studies of fossilization in second language acquisition (pp. 189-200). Clevedon, UK: Multilingual Matters.

Larsen-Freeman, D. (2006). The emergence of complexity, fluency, and accuracy in the oral and written production of five Chinese learners of English. Applied Linguistics, 27, 590-619.

Larsen-Freeman, D. (2007a). On the complementarity of chaos/complexity theory and dynamic systems theory in understanding the second language acquisition process. Bilingualism: Language and Cognition, 10, 35-37.

Larsen-Freeman, D. (2007b, April). On the nature of competence. Paper presented at the American Association for Applied Linguistics, Costa Mesa, CA.

Larsen-Freeman, D., \& Cameron, L. (in press). Complexity systems and applied linguistics. Oxford: Oxford University Press.

Larsen-Freeman, D., \& Long, M. (1991). An introduction to second language acquisition research. London: Longman.

Liddicoat, A. (1997). Interaction, social structure, and second language use. Modern Language Journal, 81, 313-317.

Long, M. (1997). Construct validity in SLA research: A response to Firth and Wagner. Modern Language Journal, 81, 318-323.

Long, M. (2007). Problems in SLA. Mahwah, NJ: Erlbaum.

Markee, N., \& Kasper, G. (2004). Classroom talks: An introduction. Modern Language Journal, 88, 491500.

McKay, S., \& Wong, S.-L. (1996). Multiple discourses, multiple identities: Investment and agency in second-language learning among Chinese adolescent immigrant students. Harvard Educational Review, 66, 577-608.

Milon, J. (1974). The development of negation in English by a second language learner. TESOL Quarterly, 8, 137-143.

Nemser, W. (1971). Approximative systems of foreign language learners. International Review of Applied Linguistics, 9, 115-124.

Norton Peirce, B. (1995). Social identity, investment, and language learning. TESOL Quarterly, 31, 409429.

Ortega, L. (2005). Methodology, epistemology, and ethics in instructed SLA research: An introduction. Modern Language Journal, 89, 317-327.

Poulisse, N. (1997). Some words in defense of the psycholinguistic approach: A response to Firth and Wagner. Modern Language Journal, 81, 324328.

Preston, D. (1996). Variationist perspectives on second language acquisition. In R. Bayley \& D. Preston (Eds.), Second language acquisition and linguistic variation (pp. 1-45). Amsterdam: John Benjamins.
Rampton, B. (1995). Crossing: Language and ethnicity among adolescents. London: Longman.

Rampton, B. (1997). Second language research in late modernity: A response to Firth and Wagner. Modern Language Journal, 81, 329-333.

Ravem, R. (1974). The development of Wh-questions in first and second language learners. In J. Richards (Ed.), Error analysis (pp. 134-144). London: Longman.

Reed, E., \& Jones, R. (Eds.). (1982). Reasons for realism: Selected essays of James J. Gibson. Hillsdale, NJ: Erlbaum.

Schlegloff, E., Jefferson, G., \& Sacks, H. (1977). The preference for self-correction in the organization of repair in conversation. Language, 53, 361-382.

Schwartz, J. (1977). Repair in conversations between adult second language learners of English. Unpublished master's thesis, University of California, Los Angeles.

Selinker, L. (1972). Interlanguage. International Review of Applied Linguistics, 10, 209-231.

Selinker, L., \& Douglas, D. (1985). Wrestling with "context" in interlanguage theory. Applied Linguistics, 6, 190-204.

Sfard, A. (1998). On two metaphors for learning and the dangers of choosing just one. Educational Researcher, 27, 4-13.

Skinner, B. F. (1957). Verbal behavior. New York: Appleton-Century-Crofts.

Smith, L., \& Thelen, E. (Eds.). (1993). A dynamic systems approach to development. Cambridge, MA: MIT Press.

Sridhar, J. (1980). Contrastive analysis, error analysis, and interlanguage. In K. Croft (Ed.), Readings on ESL for teachers, and teacher trainees (pp. 91-119). Cambridge, MA: Winthrop Publishers.

Swain, M. (2000). The output hypothesis and beyond: Mediating acquisition through collaborative dialogue. In J. Lantolf (Ed.), Sociocultural theory and second language learning (pp. 97-114). Oxford: Oxford University Press.

Tarone, E. (1983). On the variability of interlanguage systems. Applied Linguistics, 4, 142-163.

Tarone, E. (2000). Still wrestling with "context" in interlanguage theory. Annual Review of Applied Linguistics, 20, 182-198.

Tarone, E., \& Liu, G.-Q. (1995). Situational context, variation, and second language acquisition theory. In G. Cook \& B. Seidlhofer (Eds.), Principle and practice in applied linguistics: Studies in honour of H. G. Widdowson (pp. 107-124). Oxford: Oxford University Press.

Thelen, E., \& Bates, E. (2003). Connectionism and dynamic systems: Are they really different? Developmental Science, 6, 378-391.

Tomasello, M. (2000). First steps toward a usage-based theory of language acquisition. Cognitive Linguistics, 11, 61-82.

Toolan, M. (2003). An integrational linguistic view. In J. Leather \& J. van Dam (Eds.), Ecology of language acquisition (pp. 123-140). Dordrecht, The Netherlands: Kluwer Academic. 
Tucker, M., \& Hirsch-Pasek, K. (1993). Systems and language: Implications for acquisition. In L. Smith \& E. Thelen (Eds.), A dynamic systems approach to development: Applications (pp. 350-384). Cambridge, MA: MIT Press.

van Lier, L. (1994). Forks and hope: Pursuing understanding in different ways. Applied Linguistics, 15, 328-347.

van Lier, L. (2004). The ecology and semiotics of language learning. Dordrecht, The Netherlands: Kluwer Academic.

Vygotsky, L. (1962). Thought and language. Cambridge, MA: MIT Press.

Wagner, J. (2004). The classroom and beyond. Modern Language Journal, 88, 612-616.

Watson-Gegeo, K. (2004). Mind, language, and epistemology: Toward a language socialization paradigm for SLA. Modern Language Journal, 88, 331350 .

Watson-Gegeo, K., \& Nielsen, S. (2003). Language socialization in SLA. In C. Doughty \& M. Long (Eds.), The handbook of second language acquisition (pp. 155-177). Malden, MA: Blackwell.

Weinreich, U. (1953). Languages in contact. The Hague, The Netherlands: Mouton.

Wode, H. (1976). Developmental sequences in naturalistic L2 acquisition. Working Papers on Bilingualism, $11,1-31$.

Young, R. (1988). Variation and the interlanguage hypothesis. Studies in Second Language Acquisition, 10, 281-302.

Zuengler, J., \& Miller, E. (2006). Cognitive and sociocultural perspectives: Two parallel worlds? TESOL Quarterly, 40, 35-58. 